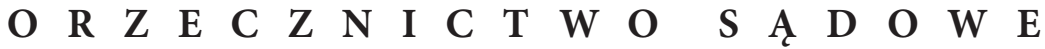

Ius Matrimoniale 32 (2021) $\mathrm{nr} 1$

ISSN 1429-3803; e-ISSN 2353-8120

DOI: http://doi.org/10.21697/im.2021.32.1.07
Artykuł jest udostępniany na zasadach licencji Creative Commons (CC BY-ND 4.0 Międzynarodowe) https://creativecommons.org/licenses/by-nd/4.0/deed.pl

open 2 access (cc)

\section{Wykluczenie dobra potomstwa oraz bojaźń szacunkowa w wyroku c. Ferreira Pena z dnia 18 kwietnia 2012 roku}

\author{
Exclusion of the good of the offspring and estimated fear in the judgment of \\ c. Ferreira Pena of 18 April 2012
}

\author{
ks. Rafał Kamiński \\ Wydział Prawa Kanonicznego UKSW \\ ORCID: 0000-0002-7822-3402 \\ e-mail: rafal.kaminski@uksw.edu.pl
}

Streszczenie: W zaprezentowanym opracowaniu autor skomentował wyrok Roty Rzymskiej c. Ferreira Pena z 18 kwietnia 2012 roku. Na stopniu rotalnym sprawa była rozpatrywana z tytułu symulacji częściowej (exclusio boni prolis) oraz z tytułu ciężkiej bojaźni (metus reverentialis).

W części prawnej rotalnego orzeczenia wykazano m.in. związek między okolicznościami życia przedmałżeńskiego oraz przyczyną symulacji konsensu małżeńskiego, do zaistnienia którego potrzebny jest pozytywny akt woli. Wskazano także na absorbcję tytułów symulacji i bojaźni, stąd też odstąpiono od orzekania z tego drugiego tytułu.

W części faktycznej natomiast ponens wskazał, że nieważność małżeństwa udowodniono przy zastosowaniu zarówno dowodzenia bezpośredniego, jak i pośredniego. W prowadzonej sprawie wykazano, iż tym co skłoniło pozwaną do symulacji, był brak miłości do pozwanego oraz poddanie się okolicznościom życia rodzinnego i presji społecznej. Udowodniono też, iż wykluczenie potomstwa przez pozwaną, było ściśle związane ze stałą praktyką przyjmowania środków antykoncepcyjnych.

Słowa kluczowe: małżeństwo kanoniczne, wada zgody małżeńskiej, symulacja, wyrok, wykluczenie dobra potomstwa, ciężka bojaźń, bojaźń szacunkowa, metus reverientalis

Abstract: In the presented study, the author commented the judgment of the Roman Rota, c. Ferreira Pena of April 18, 2012. At the Rota's stage, the case was considered for a partial simulation (exclusio boni prolis) and for severe fear (metus reverentialis).

In the legal part of the rotating judgment there was shown, among others, the relationship between the circumstances of premarital life and the reason for simulating a marital consensus, for which a positive act of will is needed. The incompatibility of the simulation and fear titles was also pointed out, hence the second title was not considered.

On the other hand, in the factual part ponens pointed out that the nullity of the marriage had been proved using both direct and indirect proving. In the case conducted it was shown that what prompted the defendant to simulate was the lack of love for the 
defendant and submission to the circumstances of family life and social pressure. It has also been proven that the exclusion of offspring by the defendant was closely related to the constant practice of taking contraceptives.

Keywords: canonical marriage, defect matrimonial consent, simulation, judgment, exclusion of the good of the offspring, severe fear, metus reverientalis

Treść: Wstęp. 1. Stan sprawy. 2. Motywy prawne. 2.1. Wykluczenie bonum prolis. 2.2. Zawarcie małżeństwa pod wpływem bojaźni. 2.2.1. Bojaźń zwyczajna (metus communis). 2.2.2. Bojaźń szacunkowa (metus reverentialis). 3. Motywy faktyczne. 4. Uwagi końcowe.

\section{Wstęp}

Przedmiotem opracowania będzie wydany 18 kwietnia 2012 roku wyrok Trybunału Apostolskiego Roty Rzymskiej. Sprawa rozpatrywana była na stopniu rotalnym z tytułu symulacji częściowej oraz bojaźni szacunkowej po stronie powódki.

\section{Stan sprawy}

Małżeństwo stron, którego dotyczy orzeczenie rotalne, zostało zawarte 12 października 1996 roku. Pochodząca z sycylijskiej wioski kobieta poznała swojego przyszłego męża, gdy przyjechał jako nastolatek na wakacje do jej miejscowości, w której się urodził i z której wraz z rodzicami przeniósł się do innego regionu. Między nastolatkami nawiązała się więź uczuciowa, która stała się dla młodej kobiety szczególnie ważna po tym, jak jej ojciec opuścił matkę i rodzinę. Również matka związała się w tym czasie z innym mężczyzną. Miało to miejsce na około cztery lata przed ślubem stron ${ }^{1}$.

Trudne dzieciństwo w wielodzietnej rodzinie, surowe warunki życia, niezgodne pożycie rodziców, niezdrowa więź z matką po jej rozstaniu z ojcem nie pozostały bez wpływu na ukształtowanie się wzorca małżeńskiego u kobiety, który poniekąd powieliła we własnym związku.

1 Por. Viglevanen. Nullitatis matrimonii. Sent. 61/2012, Dec. c. J. Ferreira Pena z 18.04.2012, RRD 104 (2012), n. 1 (dalej: Dec. c. J. Ferreira Pena z 18.04.2012). 
Kobieta, widząc trudności w domu rodzinnym, związała się z pozwanym, znajdując w małżeństwie z nim formę ucieczki od problemów i rozwiązanie przeżywanych trudności. Pod presją wywieraną ze strony matki i części rodziny zawarła małżeństwo, które jednak miało bardzo trudny przebieg. W wyniku nawiązania relacji pozamałżeńskiej z innym mężczyzną opuściła swojego męża. Dnia 14 lipca 2000 roku została orzeczona separacja kanoniczna między małżonkami².

Kobieta, jako powódka w sprawie, 21 lutego 2002 roku wniosła skargę do Sądu Regionalnego w Lombardii z tytułu wykluczenia przez siebie nierozerwalności małżeństwa oraz dobra potomstwa (kan. $1101 \S 2$ KPK/83). Sąd I instancji, 18 grudnia 2003 roku wydał wyrok negatywny co do obu tytułów ${ }^{3}$.

Powódka wniosła apelację do Trybunału Regionalnego w Ligurii. Na stopniu apelacyjnym rozszerzono formułę wątpliwości, rozpoznając sprawę w trybie zwyczajnym, nie tylko na podstawie tytułów z kan. $1101 \$ 2 \mathrm{KPK} / 83$, ale także zadając pytanie procesowe czy małżeństwo stron jest nieważne także/lub z tytułu ciężkiej bojaźni, przynajmniej szacunkowej po stronie powódki, zgodnie z kan. 1103 $\mathrm{KPK} / 83^{4}$, rozpatrując ten tytuł na stopniu apelacyjnym tamquam in prima instantia.

Na drugim stopniu została ponownie przesłuchana strona powodowa oraz trzech świadków. Dostarczono także dowody w postaci dokumentów.

23 lutego 2007 roku, Trybunał II instancji wydał wyrok pozytywny z tytułu wykluczenia dobra potomstwa oraz negatywny co do obu pozostałych tytułów.

Wobec dwóch różnobrzmiących wyroków I i II instancji co do tytułu wykluczenia potomstwa, a co za tym idzie, stwierdzeniem

2 Por. TAmże, n. 2.

3 Por. TAmże, n. 1.

4 „se la Sentenza negativa di primo grado emessa dal Tribunale Ecclesiastico Regionale Lombardo di 18 dicembre 2003 sia da confermarsi o da riformarsi e/o se consti la nullità del matrimonio anche per timore grave, almeno reverenziale, incusso sulla donna attrice, a norma del can. 1103 del CIC". Dec. c. J. Ferreira PenA z 18.04.2012, n. 2 . 
nieważności małżeństwa po raz pierwszy na stopniu apelacyjnym, istniała konieczność osądzenia sprawy na III stopniu w Trybunale Roty Rzymskiej ${ }^{5}$.

W tym stadium procesu in sede rotali, formuła wątpliwości została ustalona w następujący sposób: „Czy przedmiotowe małżeństwo jest nieważne z tytułu wykluczenia potomstwa przez kobietę, stronę powodową, rozpatrywanego na trzecim stopniu trybunału; i/lub z tytułu ciężkiej bojaźni, przynajmniej szacunkowej po stronie kobiety - powódki, rozpatrywanego na drugim stopniu trybunału"6.

\section{Motywy prawne}

W przedmiotowej sprawie, w Rocie Rzymskiej, rozpatrywane były dwa tytuły nieważności. Jeden w obrębie symulacji częściowej zgody małżeńskiej i jeden związany z bojaźnią lub przymusem towarzyszącym zawarciu małżeństwa.

Zgodnie z zasadami redakcyjnymi wyroków rotalnych na wstępie autor orzeczenia wskazuje generalną koncepcję konsensu małżeńskiego, jednakże uwypuklając szczególne znaczenie prawdy i wolności, które powinny towarzyszyć wyrażaniu zgody małżeńskiej. Tej pierwszej brakuje, kiedy zgoda małżeńska jest symulowana, ta druga doznaje uszczerbku, kiedy zgoda jest wyrażana pod wpływem ciężkiej

5 Przed rokiem 2015, kiedy to poprzez reformę procesową papieża Franciszka zniesiono wymóg dwuinstancyjności (por. FrANCISzEK, List apostolski motu proprio „Mitis Iudex Dominus Iesus”, reformujący kanony Kodeksu Prawa Kanonicznego dotyczące spraw o orzeczenie nieważności małżeństwa. List apostolski motu proprio „Mitis et misericors Iesus”, reformujacy kanony Kodeksu Kanonów Kościołów Wschodnich dotyczące spraw o orzeczenie nieważności (tekst łacińsko-polski), Tarnów 2015, kan. 1679, s. 25), dla orzeczenia nieważności małżeństwa, konieczne były dwa zgodne wyroki, wydane w obu instancjach (por. kan. 1682 i kan. 1684 KPK/83; brzmienie przed reformą).

6 „An constet de matrimonii nullitate, in casu, ob exclusum bonum prolis ex parte mulieris actricis in tertio iurisdictionis gradu; et/vel ob metum gravem, saltem reverentialem, mulieri actrici incussum in altero iurisdictionis gradu”. Dec. c. J. Ferreira Pena z 18.04.2012, n. 3. 
bojaźni wywołanej z zewnątrz ${ }^{7}$. W ten sposób ponens ukazuje relację pomiędzy dwoma tytułami, z których rozpatrywana jest sprawa.

W dalszej części uzasadnienia prawnego, autor wyroku wskazuje na doktrynę tytułu symulacji częściowej zgody małżeńskiej, polegającej na wykluczeniu dobra potomstwa, by następnie zaprezentować interpretację prawną ciężkiej bojaźni i jej dowodzenie oraz ukazać jej zaabsorbowanie przez tytuł symulacji.

Taka struktura części In iure, jest podyktowana profilem sprawy, do której stanu faktycznego odpowiednio aplikuje się normy prawne.

\subsection{Wykluczenie bonum prolis}

Symulacja częściowa, która polega na wykluczeniu pozytywnym aktem jakiegoś istotnego przymiotu małżeństwa albo istotnego elementu małżeństwa, którym w przedmiotowej sprawie jest zrodzenie i wychowanie potomstwa, musi zostać dowiedziona. Domniemywa się bowiem (praesumptio iuris tantum), że wewnętrzna zgoda odpowiada słowom lub znakom użytym przy zawieraniu małżeństwa (por. kan. $1101 \$ 2 \mathrm{KPK} / 83$ ). Takie domniemanie może zostać obalone dowodem przeciwnym na rzecz dokonanej symulacji ${ }^{8}$.

Wskazując na fenomen symulacji, ponens odnosi się do zasady prawa rzymskiego, z której korzysta doktryna i orzecznictwo, wyrażonej w paremii, zgodnie z którą uważa się, że małżeństwo pozorowane nie trwało ani przez chwilę 9 . Wywodzi się to z szerszej zasady głoszącej, że czynność prawna pozorowana jest nieważna ${ }^{10}$. W obu przypadkach, zarówno symulacji całkowitej, jak i częściowej, zgoda małżeńska jest nieskuteczna, gdyż wyrażona została w sprzeczności

\footnotetext{
7 Por. Dec. c. J. Ferreira Pena z 18.04.2012, n. 4.

8 Por. N. Schöch, Le presunzioni legali nel matrimonio: in materia di consenso (can. 1096 \& 2; 1101 \$ 1; 1107 CIC), w: Presunzioni e matrimonio, Libreria Editrice Vaticana 2012, s. 171-175.

9 „Simulatae nuptiae nullius momenti sunt”. Dig. 23, 2, 30

10 „Actus simulatus nullius est momenti”. Dig. 23, 2, 30; C. 4, 22.
} 
między wewnętrzną wolą, a wypowiedzianymi słowami, czy też wyrażonymi znakami. A zatem sam akt prawny jest nieważny ${ }^{11}$.

W kolejnym punkcie motywów prawnych, audytor rotalny przechodzi do omówienia istoty wykluczenia dobra potomstwa (bonum prolis), odwołując się przy tym do skierowania wspólnoty małżeńskiej do osiągniecia dwóch równorzędnych celów, jakimi są dobro małżonków oraz zrodzenie i wychowanie potomstwa (por. kan. $1055 \mathrm{KPK} / 83$ ).

Ponens rozważa pojęcie potomstwa $\mathrm{w}$ podwójnym aspekcie. Pierwszy z nich dotyczy małżeństwa in facto esse, kiedy to potomstwo de facto się w nim poczęło. Sytuacja ta będzie więc odnosiła się do rzeczywistości jego wychowania. Drugi aspekt, jest rozważany w kontekście małżeństwa in fieri, kiedy to intencja zrodzenia i wychowania potomstwa staje się istotnym elementem formalnym zgody małżeńskiej, a jego odrzucenie in principiis, czyni konsens małżeński bezskutecznym i nieważnym. Rozumowanie to sędzia wywodzi od nauki św. Tomasza z Akwinu ${ }^{12}$. Akwinata dokonał rozróżnienia pomiędzy potomstwem samym w sobie (proles in se ipsa) i potomstwem w swoich zasadach (proles in suis principiis). Potomstwo ujęte w swych zasadach, jako przedmiot intencji konsensualnej, przekazuje się we wzajemnym oddaniu ciał kontrahentów dla spełnienia copula coniugalis, gdyż jedynie poprzez to przekazanie możliwe jest osiągnięcie naturalnej konsekwencji w postaci prokreacji ujmowanej in se ipsa, czyli faktycznego zrodzenia potomstwa. Jak wynika ze sformułowania św. Tomasza, nie ma żadnego obowiązku posiadania pozytywnej woli zrodzenia potomstwa, wystarczy, by nie unikać poczęcia lub nie przeszkadzać w narodzeniu poczętego dziecka ${ }^{13}$.

Jest rzeczą oczywistą, na którą autor sentencji zwraca uwagę, że w kanonicznym porządku prawnym relewantne jest małżeństwo,

\footnotetext{
11 Por. G. Dzierżon, Niezdolność do zawarcia matżeństwa jako kategoria kanoniczna, Warszawa 2002, s. 25-60.

12 Por. S. Thomas Aq., Summa Theologica, Suppl., q. 49, art 3; Dec. c. J. Ferreira PENA Z 18.04.2012, n. 6;

13 Por. P. Fedele, L',oridantio ad prolem” nel matrimonio canonico, Milano 1962, s. 323.
} 
w którym nie pocznie się potomstwo, na co wskazuje chociażby hipoteza kan. $1084 \$ 3 \mathrm{KPK} / 83$, stanowiąca, że niepłodność nie powoduje nieważności umowy małżeńskiej. Nigdy jednak nie będzie ona ważna bez intencji przyjęcia potomstwa i jego religijnego wychowania ${ }^{14}$.

W dalszej kolejności, ponens rotalny prowadzi swoje rozważania w kwestii podstaw prawnych, w kierunku wykluczenia potomstwa oraz odłożenia jego poczęcia w czasie, co stanowi zasadniczą różnicę. Aby małżeństwo było ważnie zawarte, pisze audytor, nupturienci nie mogą wykluczać wzajemnego prawa do aktu małżeńskiego samego przez się zdolnego do zrodzenia potomstwa, do którego małżeństwo jest ukierunkowane ze swej natury (por. kan. $1061 \$ 1$ KPK/83). Należy jednak, jak podkreśla sędzia, rozróżnić między wykluczeniem prawa jako takiego (exclusio ipsius iuris), a odmową do korzystania z niego czy też jego nadużywaniem (exercitium iuris) ${ }^{15}$. Pierwsze działanie czyni małżeństwo nieważnym, drugie zaś, jest działaniem nagannym moralnie, lecz nie powoduje nieważności konsensu, ponieważ nie jest całkowitym negowaniem możliwości poczęcia się potomstwa ${ }^{16}$. Istnieje tutaj, jego zdaniem, zasadnicza różnica dotycząca przedmiotu symulacji, a także intencji domniemanego symulanta ${ }^{17}$.

Utrwalona opinia, przyjęta przez judykaturę rotalną, na którą wskazuje się w tej części wyroku, odnosi się także do czasu wykluczenia. Uznaje się, że stałe i absolutne unikanie aktów małżeńskich (exclusio absoluta et perpetua) godzi bezpośrednio w samo do nich prawo, natomiast czasowe unikanie aktów zdolnych do poczęcia, uznaje się za odmowę lub ograniczenie prawa do jego realizacji, nie naruszające jednakże, co do zasady, samego konsensu ${ }^{18}$. Istnieją jednak przypadki, zauważa ponens, w których także czasowe unikanie współżycia, godzi w samo prawo do aktu małżeńskiego (ius ipsum

\footnotetext{
14 Por. Dec. c. J. Ferreira Pena z 18.04.2012, n. 6.

15 Por. TAmże, n. 7.

16 Por. TAMżE.

17 Por. Dec. C. Ciani z 30.10.2002, RRD 94 (2002), s. 592.

18 Por. Dec. c. Stankiewicz z 29.07.1980, RRD 72 (1980), s. 559-563; Dec. c. Felici z 11.01.1955, SRRD 47 (1955), s. 32; Dec. c. Pinto z 28.10.1983, RRD 75 (1983), s. 559.
} 
pertingit). Znane są orzecznictwu rotalnemu kazusy, w których nupturient zawierając małżeństwo nie tyle zawiesza czasowo prawo-obowiązek korzystania z naturalnych aktów małżeńskich, zdolnych do poczęcia potomstwa, ale uzależnia je od powodzenia wspólnego życia w przyszłości i udziela tego prawa do czasu, gdy wspólnota małżeńska będzie udana. W takim przypadku przekazanie ius ad prolem nie jest absolutne i udzielone na zawsze, a tym samym skutkuje nieważnością małżeństwa ${ }^{19}$.

Po wyjaśnieniu istoty symulacji częściowej konsensu małżeńskiego, polegającej w tym przypadku na wykluczeniu dobra potomstwa, w kolejnym punkcie części in iure ponens przypomina, że do zaistnienia jakiejkolwiek formy symulacji potrzeba zaistnienia pozytywnego aktu woli symulanta, jakim się ona dokonuje ${ }^{20}$. Akt ten, aby miał skutki niweczące zgodę małżeńską, powinien zostać powzięty w momencie zawierania małżeństwa, albo też jeszcze przed jego zawarciem i nie zostać odwołanym. Sędzia, opisując wolę, jako przyczynę sprawczą, rozróżnia wolę aktualną (voluntas actualis), która działa w momencie celebracji; wolę wirtualną (voluntas virtualis) ujawniającą się przed zawarciem małżeństwa i trwającą w czasie celebracji; oraz wolę habitualną (voluntas habitualis), która jednak, w odróżnieniu od dwóch pierwszych rodzajów, nie dochodzi do głosu w czasie celebracji, a jest niejako stałym usposobieniem, predyspozycją nupturienta, która jeśli nie prowadzi do konkretnej decyzji, nie wywołuje tym samym skutków unieważniających.

Jest zatem kwestią do ustalenia, czy wola habitualna nupturienta została zaangażowana poprzez konkretny pozytywny akt w przedmiocie i w kierunku symulacji, czy też nie. Sędzia zwraca uwagę, że niewystarczające jest w tym względzie przekonanie czy też opinia

19 Por. Dec. c. Burke z 19.10.1995, RRD 87 (1995), s. 562; Dec. c. Boccafola z 17.01.2002, RRD 94 (2002), s. 5; Dec. c. BRUno z 15.04.1983, RRD 75 (1983), s. 165; Dec. c. Monier z 12.04.2002, RRD 94 (2002), s. 245; Por. W. Góralski, Matrimonium facit consensus. Z orzecznictwa Trybunału Roty Rzymskiej w sprawach o nieważność małżenstwa rozpoznanych z tytułów dotyczących zgody małżeńskiej (1997-2016), t. 3., Płock 2018, s. 288.

20 Por. Dec. c. J. Ferreira Pena z 18.04.2012, n. 8. 
przeciwna posiadaniu potomstwa w małżeństwie, niechęć do dzieci, czy też do posiadania ich większej liczby. Tylko jeśli zostanie udowodnione powzięcie pozytywnego aktu woli, motywowanego powyższymi przekonaniami, można orzec nieważność małżeństwa z tytułu symulacji.

Kontynuując kwestię dowodzenia, autor wyroku wskazuje zarówno na środki bezpośrednie, jak i pośrednie.

Podstawowe znaczenie w pierwszej grupie środków posiada przyznanie symulanta (confessio simulantis), zarówno sądowe, jak i pozasądowe. Pierwszeństwo przyznaje się, rzecz jasna, takiemu przyznaniu, którego dokonuje się przed sędzią, lecz swoją istotną wartość posiada także i to, które dokonało się w czasie niepodejrzanym przed wiarygodnymi świadkami, którzy potwierdzą to w czasie zeznań ${ }^{21}$.

W praktyce procesowej częściej będzie możliwe jednak skorzystanie $z$ dowodów pośrednich. Pożyteczne będzie zatem zbadanie przyczyn dalszych i bliższych, które mogłyby skłaniać nupturienta ku symulacji konsensu. Wśród posiadających szczególne znaczenie ponens wyróżnia awersję do ojcostwa lub macierzyństwa, albo też podzielanie teorii o przeludnieniu świata, jeszcze inne przyczyny to obawa o brak dzielenia autentycznej miłości w związku, nieufność w zbudowanie przyszłej jedności, czy też obawa przed urodzeniem dzieci dotkniętych chorobą ${ }^{22}$.

Poza przyczynami, które mogą wywołać wolę symulacji, autor omawianego wyroku zwraca uwagę na konieczność porównania przyczyny zawarcia (causa nubendi) i przyczyny symulacji (causa simulandi), występujących w umyśle kontrahenta oraz zbadanie ich wzajemnego wpływu na siebie, oraz określenia, która z przyczyn przeważa $^{23}$.

W orzecznictwie Roty Rzymskiej wprowadzono rozróżnienie między wyżej wspomnianymi przyczynami, stojąc na stanowisku, że zawsze współzawodniczą ze sobą lub też stawiając przyczynę zawarcia

\footnotetext{
21 Por. TAmże, n. 9.

22 Por. TAMŻE.

23 Por. TAMżE.
} 
małżeństwa w opozycji do przyczyny symulacji i niepozwalając ich ze sobą mieszać ${ }^{24}$.

Na koniec omawiania podstaw prawnych symulacji częściowej poprzez wykluczenie bonum prolis autor sentencji zwraca uwagę, że przy dowodzeniu tego tytułu należy uwzględnić wszystkie okoliczności, które miały miejsce zarówno przed, jak i po zawarciu małżeństwa. Do takich okoliczności zalicza używanie w pożyciu intymnym antykoncepcji, jej rodzaju oraz stałości i czasu trwania tej praktyki, oraz krótki czas trwania wspólnoty życia małżeńskiego ${ }^{25}$.

\subsection{Zawarcie małżeństwa pod wpływem bojaźni}

\subsubsection{Bojaźń zwyczajna (metus communis)}

Rozpoczynając wywód na temat drugiego tytułu, z którego prowadzona była sprawa, ponens rotalny czyni rozróżnienie między bojaźnią pochodzącą z wnętrza człowieka (metus ab itrinseco), eksponując brak wolności wewnętrznej, jaka może mieć miejsce przy poważnym braku rozeznania oceniającego co do istotnych obowiązków małżeńskich (por. kan. 1095 n. 2 KPK/83), a interesującą nas w przedmiotowym procesie ciężką bojaźnią pochodzącą z przyczyny zewnętrznej (metus gravis ab extrinseco), to znaczy wolnej i ludzkiej, o której w kan. $1103 \mathrm{KPK} / 83^{26}$.

24 Dec. c. Di Felice z 29.03.1969, SRRD 61 (1961), s. 349; Dec. c. Di Felice z 25.06.1971, SRRD 63 (1971), s. 530; Dec. c. EwERS z 13.02.1965, SRRD 57 (1965), s. 142; Dec. c. De Jorio z 22.01.1969, SRRD 61 (1969), s. 70; Dec c. Pinto z 30.07.1969, SRRD 61 (1969), s. 903; Dec. c. De Jorio z 8.01.1971, SRRD 73 (1971), s. 4; Dec. c. Ewers z 19.04.1972, SRRD 74 (1972), s. 181; Dec. c. BRUNo z 8.07.1975, SRRD 67 (1975), s. 476; Dec. c. Di Felice z 16.10.1976, SRRD 68 (1976), s. 367; Dec. c. PARISELla z 16.06.1983, SRRD 75 (1983), s. 343; Dec. c. LANVERSIn z 21.02.1990, RRD 82 (1990), s. 111; Dec. c. LAnversin z 31.07.1990, RRD 82 (1990), s. 679; Por. B. Glinkowski, Symulacja całkowita zgody małżeńskiej w orzecznictwie Roty Rzymskiej (1965-1995), Poznań 2004, s. 55.

25 Por. Dec. c. J. Ferreira Pena z 18.04.2012, n. 9.

26 Ponens przypomina, że przepis obecnie obowiązujący, bazuje substancjalnie na normie kan. 1087 CIC/17, z wyjątkiem zmian dotyczących ciężkości bojaźni i nieumyślnego jej wywołania, które zostały wprowadzone na podstawie praktyki 
Jego zdaniem, z brzmienia normy wynikają cechy, które musi posiadać bojaźń, aby skutkowała ona nieważnością konsensu małżeńskiego. Przede wszystkim chodzi o jej ciężkość, którą należy mierzyć nie tylko obiektywnie, tj. według grożącego zła, ale także według kryteriów subiektywnych, tj. stosownie do jego wpływu na wolę ulegającego bojaźni ${ }^{27}$. A zatem jest istotne, czy nupturient zawierał małżeństwo z powodu bojaźni (ex metu), czy tylko przeżywając bojaźń (cum metu). W drugim przypadku bojaźń, której uległ nupturient, jak to określił, „skaża” zgodę, ale nie czyni jej nieważną ${ }^{28}$.

Drugim podstawowym wymogiem postawionym w kan. 1103 jest niezmienność (indeclinabilitas) wywołanej bojaźni. Nie będzie miała charakteru relewatnego bojaźń, której ciężkość została „pomniejszona" przez samego nupturienta, na skutek zmniejszenia się realnego wpływu grożącego mu zła, tak że mógł on wybrać inny środek niż zawarcie małżeństwa, aby się od niego uwolnić. Jest oczywistym, co zaznacza ponens, że należy zawsze uwzględnić konkretne uwarunkowania osobiste i egzystencjalne kontrahenta poddanego bojaźni ${ }^{29}$.

Nie jest wymagane, jak w kodeksowej normie z roku 1917, aby bojaźń została wywołana umyślnie (por. can. 1087 CIC/17). Swój skutek może wywołać także strach powodujący ograniczenie wolności przy zawieraniu małżeństwa, sprowokowany przyczyną pośrednią. Jako przykład audytor podaje obawę przed doznaniem uszczerbku na honorze rodziny ${ }^{30}$.

orzeczniczej w sprawach rozpatrywanych z tego tytułu. Por. Dec. c. J. FerReira Pena z 18.04.2012, n. 10. CIC/17: Can. $1087 \$ 1$. Invalidum quoque est matrimonium initum ob vim vel metum gravem ab extrinseco et iniuste incussum, a quo ut quis se liberet, eligere cogatur matrimonium. $\$ 2$. Nullus alius metus, etiamsi det causam contractui, matrimonii nullitatem secumfert.

CIC/83: Can. 1103. Invalidum est matrimonium initum ob vim vel metum gravem ab extrinseco, etiam haud consulto incussum, a quo ut quis se liberet, eligere cogatur matrimonium.

${ }_{27}$ Por. W. Góralski, Matromonium facit consensus..., s. 482.

28 Por. TAMżE, s. 483.

29 Por. Dec. c. J. Ferreira Pena z 18.04.2012, n. 10.

30 Por. TAmżE. 
Nie wymaga się również już więcej, obiektywnej niesprawiedliwości w wywołaniu bojaźni (iniustitia metus), jak miało to miejsce w poprzedniej regulacji, wystarczy bowiem by strach powodował ograniczenie wolności wyboru u konkretnego nupturienta, który odczuwa to jako niesprawiedliwość ${ }^{31}$.

\subsubsection{Bojaźń szacunkowa (metus reverentialis)}

Szczególną formą, na którą zwraca uwagę Ferreira Pena, z uwagi na powoływanie się na nią ze strony powódki, jest tzw. bojaźń szacunkowa (metus reverentialis). Tego rodzaju bojaźń polega na obawie zła płynącego z nieposłuszeństwa, gdy ktoś czyni coś z powodu lęku przed obrazą wobec tych, którym winien okazywać cześć i posłuszeństwo ${ }^{32}$.

Należy na podstawie obiektywnych i subiektywnych kryteriów odróżnić ją od zwykłego respektu czy też wymaganego zwyczajnie szacunku.

Od strony subiektywnej należy zbadać relację, jaka w konkretnym przypadku zachodzi między bojaźnią wzbudzaną przez tych, którym należy się szacunek, a wynikającym z zasad życia rodzinnego i społecznego respektem, który jest rzeczą naturalną, wynikającą z relacji uczuciowych i prawnych. Dla zobrazowania tego ponens sięga po przykład relacji rodziców i dzieci ${ }^{33}$.

Od strony obiektywnych okoliczności, dotknięty bojaźnią może w tym przypadku obawiać się zła, które może go dotknąć. Będzie to zazwyczaj strach przed poważnym, długotrwałym oburzeniem, utratą dobrej opinii czy też uczuć rodzicielskich. Środki, jakimi mogą posłużyć się osoby, które wzbudzają bojaźń, to uciążliwe narzekania, skargi i nalegania, podstępne obwinianie, które mają w nupturiencie

\footnotetext{
31 Por. TAmże.

32 Por. Dec. c. Sabatini z 11.11.1962, RRD 52 (1962), s. 477; Dec. c. Stankiewicz z 12.07.1966, RRD 88 (1996), s. 508; Dec. c. ERLEBACH z 13.12.2007, RDD 99 (2007), s. 338 .

33 Por. Dec. c. J. Ferreira Pena z 18.04.2012, n. 10.
} 
wywołać przerażenie ${ }^{34}$. Są to zatem wirtualne groźby, które są w stanie wywołać bojaźń szacunkową.

Aby uwolnić się od lęku, nupturient z obawy przed niebezpieczeństwem zawiera małżeństwo (ex metu). Wybiera je niejako z własnej woli, ale w rzeczywistości jest to wola, która została narzucona mu przez rodzica, której nie mógł się oprzeć, nie mógł przezwyciężyć inaczej jak wybierając małżeństwo, by nie popaść w niełaskę rodziców ${ }^{35}$.

W kwestii dowodzenia z tytułu ciężkiej bojaźni panuje określona dyscyplina, na co zwraca uwage ponens Ferreira Pena. Dowodzenie to może odbywać się na drodze bezpośredniej lub pośredniej. Innymi słowy należy udowodnić przymus i awersję (coactio et aversio) ${ }^{36}$. Ten pierwszy nie jest niczym innym, jak dowiedzeniem, że nupturient działał „przymuszony” ciężką bojaźnią lub poważnie ograniczoną wolnością. Środkami dowodzenia będą tu wiarygodne zeznania, które potwierdzą, że bojaźń ta była czymś więcej niż należnym respektem. Świadkowie powinni potwierdzić presję ze strony grożącego oraz strach nupturienta przed groźbami, który skierował go do zawarcia małżeństwa ${ }^{37}$.

Udowodnienie awersji jest uznawane za dowód koronny w dowodzeniu bezpośrednim. Można bowiem domniemywać, że jeśli ktoś miał wewnętrzną niechęć w stosunku do samej osoby, albo też do samego małżeństwa z nią, a mimo to je zawarł, został do tego zmuszony.

Awersja ta musi istnieć nie tylko w czasie prowadzenia dowodzenia, ale nade wszystko musiała zaistnieć jeszcze przed zawarciem związku i towarzyszyć wzajemnej relacji. W przebiegu małżeństwa może się ona, zdaniem ponensa, pojawić przecież także z innych przyczyn, jak: oziębłość, wygaśnięcie pierwotnego uczucia, lepsze

\footnotetext{
34 Por. TAMżE, n. 10.

35 Por. TAmże; por. Dec. c. Deffilippi z 13.07.2000, A. 77/00, n. 15 (nieopublik.); por. W. Gór alski, Matromonium facit consensus..., s. 483.

36 Por. Dec. c. J. Ferreira Pena z 18.04.2012, n. 11.

37 Por. TAmżE.
} 
poznanie negatywnych cech charakteru współmałżonka, czy tė̇ pojawienie się uczucia do innej osoby ${ }^{38}$.

Na zakończenie motywów prawnych, autor wyroku zwraca uwagę, że sprawa rozpatrywana jest z dwóch tytułów: symulacji i ciężkiej bojaźni. Jakkolwiek, jego zdaniem, może istnieć psychologiczny związek między nimi, to od strony prawnej są one trudne do pogodzenia. Podczas gdy symulacja wyklucza zgodę małżeńską (involuntarium simpliciter), ciężka bojaźń zakłada prawdziwy konsens, ale czyni go wadliwym i prawnie nieskutecznym (involuntarium secundum quid; coactus tamen voluit) $)^{39}$.

W konsekwencji, w przedmiotowej sprawie audytorzy rotalni będą orzekać tylko z jednego z dwóch tytułów, to jest symulacji częściowej. Racją prawną dla takiej decyzji było rozpatrywanie tego tytułu już od I instancji, jako braku woli do wyrażenia zgody, a tym samym wyklucza to badanie sprawy pod kątem wadliwego jej wyrażenia, mimo woli do zawarcia małżeństwa jako takiego ${ }^{40}$.

\section{Motywy faktyczne}

Na początku uzasadnienia faktycznego wyroku ponens zwraca uwagę na wątpliwości dotyczące cech i postaw stron, którymi charakteryzowały się w okresie przedmałżeńskim, a które słusznie podniósł w swoim orzeczeniu trybunał drugiej instancji. Już w tym okresie, jak pisze, dała się zauważyć nadmierna miłość własna, niedojrzałość, niechęć do poświęcenia jednej strony dla drugiej oraz brak woli wzajemnego wspierania się i pomocy. Tego typu postawy świadczą, zdaniem sądu, o braku predyspozycji do dokonania dojrzałego i w pełni świadomego wyboru, jakim jest zawarcie małżeństwa ${ }^{41}$.

Nie bez znaczenia, w kontekście rozpatrywania sprawy z tytułu symulacji, ale także w kontekście wniesionego tytułu ciężkiej bojaźni,

\footnotetext{
38 Por. TAMżE.

39 Por. TAMŻE, n. 12.

40 Por. TAMŻE, n. 12.

41 Por. TAmŻE, n. 13.
} 
jest środowisko rodzinne nupturientów. Przedstawione w czasie instrukcji sprawy fakty potwierdzają, że ograniczenia wynikające z życia rodzinnego i społecznego, w jakich przyszło dorastać powódce, poniekąd zmusiły ją do zawarcia małżeństwa, które traktowała jako ucieczkę od sytuacji rodzinnej, ale do którego nie była przekonana, i którego nie chciała zawierać. To będzie zresztą wpływać znacząco na wspólne życie stron po ślubie. W tym kontekście ponens podkreśla, że zachowania powódki i jej sposób działania, zostały ocenione przez sąd pierwszej instancji jako zmienne i porywcze, co świadczy o jej niestabilności.

W ocenie turnusu rotalnego, wpływ na takie uwarunkowania powódki miało z pewnością jej surowe wychowanie i funkcjonowanie w małej społeczności lokalnej. Postawa matki przynaglającej ją do zawarcia małżeństwa, osąd moralny, wreszcie chęć ochrony własnej reputacji sprawiły, że powódka zdecydowała się na małżeństwo, chociaż nie miała woli jego zawarcia. Audytorzy turnusu nie mają wątpliwości, że opisane przez powódkę powyższe okoliczności były konieczne w zrozumieniu kontekstu sprawy, a ją samą uznają za osobę szczerą i godną zaufania ${ }^{42}$. Ma to zasadnicze znaczenie w kontekście dowodzenia symulacji, do którego powrócimy w dalszej części.

$\mathrm{W}$ opinii ponensa orzeczenie trybunału pierwszej instancji jest niejednoznaczne. Ocena dowodów dokonana na tym stopniu została poddana krytyce. Z jednej strony sędziowie nie odrzucili twierdzeń powódki, a opisane przez nią okoliczności życia rodzinnego i społecznego, które przymusiły ją do zawarcia małżeństwa bez miłości uznali za dostatecznie wyjaśnione. Ocenili jednak zachowania powódki jako niezgodne z doktryną katolicką, choć jak zarzuca autor sentencji rotalnej, wiele aspektów instrukcji sprawy i ocena dowodów została dokonana bez należytej staranności ${ }^{43}$. Z drugiej strony w całej sprawie większą wartość zdają się przyznawać wiarygodności pozwanego, mimo że nie wynika ona z przeprowadzonej instrukcji. Szczególnie ta postawa orzekających w pierwszej instancji spotkała

\footnotetext{
42 Por. TAMżE.

43 Por. TAMżE, n. 14.
} 
się z krytyką turnusu rotalnego. Zarzucono im, że w wyrokowaniu kierowali się z góry powziętymi sądami (praeiudicium), które przeszkodziły w słusznym rozważeniu argumentów, a nawet spowodowały poważne zaniedbania w ocenie istotnych dowodów na poparcie tezy powodowej $^{44}$.

Znaczna część uzasadnienia faktycznego została poświęcona postawie procesowej stron i ich wiarygodności, co zostało już wspomniane wyżej, a także ich charakterystyce od strony charakterologicznej, w której nie brak także odniesienia do praktykowania wiary. Audytor zauważa, że sędziowie pierwszej instancji ocenili pozwanego, jako niezbyt pomocnego w dotarciu do obiektywnej prawdy o przedmiotowym małżeństwie („poco coretto”) ${ }^{45}$. Został on oceniony jako niezbyt gorliwy chrześcijanin. Nie był także zainteresowany przebiegiem procesu, a do trybunału zgłosił się na skutek interwencji własnego proboszcza. Jego zeznaniom, jakoby żona miała oferować mu pieniądze, aby nie stawał na przeszkodzie orzeczeniu nieważności w procesie, sędziowie pierwszej instancji przyznali znaczącą wartość („rilevante”), opierając się jedynie na opinii proboszcza, który jednakże nigdy wcześniej nie spotkał pozwanego, ale przypuszczał, że pozwany jest szczery i świadomy popełnionego błędu, jednak nie jest

\footnotetext{
44 TAmżE. Ponens przytacza dla przykładu zignorowanie przez sąd pierwszej instancji dowodu $\mathrm{z}$ dokumentów, w postaci pięciu telegramów powódki do pozwanego, z których jasno wynika, że chciała ona zerwać z nim przedślubną relację. Pozwany próbował pomniejszać ich znaczenie, a Sąd interpretował ich treść jako wątpliwości powódki, które przeważnie towarzyszą decyzjom dotyczącym przyszłości i zawarciu małżeństwa. Fakty, zdaniem Sądu I instancji, nie przeczyły temu, że powódka może być „w jakiś sposób zakochana w pozwanym”. „Fatti non tolgono comunque l'eventualità che Simona fosse in qualche modo innamorata di Gianluca e che le minacce del ragazzo l'abbiano pertanto convinta a superare delle titubanze connesse prevalentemente a dubbi sulla futura intesa”. Dec. c. J. Ferreir a Pena z 18.04.2012, n. 14. Trybunał stopnia apelacyjnego ocenił odmiennie dostarczone dokumenty, widząc w nich dowód, który w wyraźny sposób potwierdza tezę powódki o niechęci zawierania małżeństwa z pozwanym. „Inoltre, sempre in merito alla credibilità accordata a Gianluca, la Sentenza ha preferito glissare di fronte a prove documentali di plateale chiarezza: mi riferisco ai telegrammi che egli mi indirizzò". TAмżE.

45 Por. TAmżE, n. 14.
} 
w stanie wesprzeć swej tezy o ważności małżeństwa, które zostało zawarte $\mathrm{z}$ miłości dwojga osób ${ }^{46}$.

Ta negatywna ocena, dotycząca bezkrytycznego przyjęcia opinii kapłana na temat pozwanego, doznaje dodatkowego wzmocnienia poprzez uwagę ponensa, który dostrzega, że w ocenie materiału dowodowego całkowicie została pominięta opinia innego duchownego, wikariusza sądowego, z którym powódka konsultowała swój przypadek, i który zachęcał ją do złożenia skargi sądowej. Kapłan ten ocenił powódkę jako szczerą i wiarygodną, o czym świadczy bardzo spójne i nie przeczące sobie przedstawianie faktów, a także to, że nie kierowała pod adresem matki i męża żadnych pretensji czy też niechęci ${ }^{47}$.

Znaczenie, jakie przypisali audytorzy turnusu wiarygodności stron, ich prawdomówności i postawie w czasie procesu, jest szczególnie przydatne w dowodzeniu symulacji, której istota polega na zgodności wewnętrznej woli z uzewnętrzniającymi ją słowami i czynami. Przyznanie się strony do symulowania konsensu, musi zostać poparte przez jej postawę, ale także potwierdzone przez wiarygodnych świadków, którzy posiadają wiedzę z okresu niepodejrzanego.

W dowodzeniu symulacji częściowej, polegającej na wykluczeniu zrodzenia i wychowania potomstwa w małżeństwie z pozwanym, sędziowie oparli się właśnie na tym klasycznym dowodzie bezpośrednim jakim jest przyznanie symulanta (confessio simulantis).

Turnus rotalny stwierdza, że już w trybunale pierwszego stopnia zeznania powódki zawierały wiele jego elementów, a na stopniu apelacyjnym dostarczyła ona w tej materii nowe elementy. Audytor zauważa, że matka powódki, która w zeznaniach sądu w Mediolanie zaprzeczała wykluczeniu przez powódkę posiadania potomstwa, w ponownych zeznaniach dostarczyła potwierdzenia tego faktu. Początkowo wydawało się jej bowiem, że deklaracje córki o niechęci

\footnotetext{
46 „sincero e consapevole dell'errore compiuto ma non disposto a sostenere una validità del matrimonio che era nato dall'amore sincero di due persone”. TAMżE. 47 „sincera e attendibile perché, nell'esporre i fatti, è stata molto lineare e non è caduta in contraddizione e non ha avuto parole di rancore e di astio né verso la madre né verso Gianluca”. TAмżE.
} 
posiadania dzieci z pozwanym były oznaką jej niedojrzałości, która minie. Z perspektywy czasu oceniła to jednak inaczej, szczególnie w kontekście wiedzy o przyjmowaniu przez powódkę doustnych środków antykoncepcyjnych. Niechęć tę i decyzję, którą podjęła powódka jeszcze przed zawarciem małżeństwa, potwierdza także jej serdeczna przyjaciółka ${ }^{48}$.

Szczególne znaczenie, w ocenie ponensa rotalnego, mają zeznania farmaceutów, którzy przez lata sprzedawali powódce środki antykoncepcyjne, oraz lekarza, który je przepisywał. Pierwszy z nich w pisemnej relacji, sporządzonej na prośbę kobiety, potwierdza jej trudną sytuację rodzinną, o której mu opowiadała oraz jej wolę nieposiadania potomstwa. W obszernym fragmencie przytoczonych zeznań, świadek ten twierdzi, że relacja z pozwanym była dla powódki formą ucieczki od dotychczasowego życia. Pod wpływem presji społecznej i kulturowej, wyszła za niego za mąż. Od początku trwania małżeństwa zaopatrywała się w środki antykoncepcyjne, przy czym wciąż się upewniała o ich skuteczności, chcąc z całą pewnością uniknąć poczęcia. Także po przeprowadzce do Lombardii, wracając na wakacje do rodzinnej miejscowości kontynuowała kupno środków antykoncepcyjnych u miejscowego farmaceuty, co świadczy o stałości tej praktyki w całym pożyciu małżeńskim i wierności decyzji o wykluczeniu potomstwa, co zresztą przyznawała w rozmowach z zeznającym aptekarzem ${ }^{49}$.

Inny farmaceuta, przyjaciel powódki, zeznał, że ona nie chciała wyjść za mąż za pozwanego i mieć z nim dzieci, ponieważ nigdy go nie kochała. Także ten świadek dostarczał kobiecie środki antykoncepcyjne, zarówno przed jak i po ślubie z pozwanym. Miały one zapobiec ciąży, a przyjmowanie ich nie miało żadnych podstaw terapeutycznych ${ }^{50}$.

W materiale dowodowym znajduje się także list lekarza wysłany do powódki, w którym odmawia on złożenia zeznań, z powodu

\footnotetext{
48 TAMŻE, n. 15

49 TAMŻE.

50 TAMŻE.
} 
tajemnicy zawodowej, która obejmuje intymne szczegóły życia kobiety. Jednak z jego pisma, cytowanego w orzeczeniu rotalnym wynika, że w latach 1992-1996, przepisywał na jej wyraźne życzenie, środki antykoncepcyjne.

Także jakiś czas po ślubie, pozostając jej lekarzem, posiadał wiedzę o tym, że stale przyjmuje antykoncepcję w celu uniknięcia poczęcia potomstwa $^{51}$.

Turnus rotalny na podstawie powyższych zeznań potwierdza istnienie pozasądowego przyznania powódki, uczynionego wobec wiarygodnych świadków w czasie niepodejrzanym. Jest ono świadectwem woli symulowania wyrażenia zgody małżeńskiej z jej strony, o czym wiarygodnie zeznaje w obu instancjach, mimo że jest to dla niej wstydliwa okoliczność. Nawet jeśli w jej przekonaniu symulacja bardziej dotyczy nierozerwalności niż posiadania potomstwa, jej wyznanie jest szczere. Przyznaje, że nie jest w stanie przedstawić świadków swojej woli symulowania konsensu, przez wykluczenie nierozerwalności, gdyż nikomu tego wprost nie wyznawała, z powodu swej dość zamkniętej osobowości. Czuła się jednakże związana sposobem wychowania domowego i szkolnego, by w wyniku długiego narzeczeństwa zawrzeć małżeństwo. Jedyną osobą, której mogłaby wtedy zaufać była jej matka, ale ona była tą, która do małżeństwa ją zmuszała $^{52}$.

Redaktor wyroku zauważa, że z zeznań stron wyraźnie wynikają dowody potwierdzające tezę powodową dotyczącą symulacji. Sytuują się one między dowodzeniem bezpośrednim i pośrednim. Opisane okoliczności życia powódki w pełni naświetlają jej decyzję o unikaniu potomstwa i symulowaniu woli zawarcia małżeństwa ${ }^{53}$.

Przyczyny symulacji (causa simulandi) należy zdaniem audytora upatrywać w modelu życia, który panował w małej społeczności sycylijskiej wioski w ówczesnym czasie, który w jakimś sensie wymuszał podejmowanie decyzji, także w kierunku małżeństwa, któremu

\footnotetext{
51 TAMŻE.

52 TAMŻE, n. 16.

53 Por. TAMżE.
} 
kobieta nie potrafiła się oprzeć, mimo swego charakteru. Warunki jej życia zbyt pospiesznie pchnęły ją do zamążpójścia, bez należytej dojrzałości oraz przy naleganiu matki, którą nie kierowało dobro jej dziecka, ale konieczność poszukiwania własnej wolności ${ }^{54}$.

Ponadto sędziowie zauważają, że brak woli zawarcia małżeństwa ze strony kobiety można wyprowadzić z kilku źródeł, ale na pierwszym miejscu należy zauważyć brak miłości między stronami. W cytowanych zeznaniach przyznaje ona, że po pięciu latach narzeczeństwa odkryła, że nic ich nie łączyło; nie była w pozwanym już zakochana, a jej zauroczeniem w wieku czternastu lat kierowała bardziej możliwość wyjścia z domu i wyzwolenia się z dotychczasowych warunków życia.

Kilku prób zerwania relacji narzeczeńskiej z mężczyzną dowodzą wysyłane do niego telegramy, w których prosiła go o niekontynuowanie związku i zaprzestanie przygotowań do ślubu. Przyczyną zaś wykluczenia bonum prolis, były wątpliwości co do planowanego małżeństwa stron, a następnie zupełne jego odrzucenie. Audytorzy rotalni są przekonani, że kobieta nie chciałaby, aby w tym związku narodziły się dzieci ${ }^{55}$.

W ostatnim punkcie motywów faktycznych wydanego orzeczenia jego autor odnosi się do drugiego tytułu, który był rozpatrywany przez Trybunał Roty Rzymskiej, a mianowicie nieważność małżeństwa zawartego pod wpływem ciężkiej bojaźni szacunkowej, którą miała wzbudzić w powódce jej matka.

Sędziowie przyznają, że trudno jest zrozumieć naturę i intensywność nalegania ze strony matki, aby córka jak najszybciej zawarła małżeństwo i opuściła dom rodzinny. Ich zdaniem trudno było także dowieść, czy miało to charakter poważnej groźby czy też raczej usilnej prośby. Według turnusu w zaistniałej wątpliwości faktycznej (in dubio) aplikacja normy kanonu 1103 KPK/83 nie jest możliwa. Dlatego rotalne kolegium sędziowskie przyznało rację sędziom sądu apelacyjnego, który optował za symulacją kobiety; ta opcja, w ich przekonaniu osłabia jednocześnie fundament tytułu ciężkiej bojaźni,

54 Por. TAMżE.

55 Por. TAmże, n. 17. 
pod wpływem której rzekomo miało zostać zawarte małżeństwo. Jeśli zatem, argumentują, przyjąć tytuł symulacji za udowodniony i osadzony w kontekście potraktowania zawarcia małżeństwa nie w jego rzeczywistym znaczeniu wspólnoty całego życia, ale jako ucieczkę od rzeczywistości rodzinnej, wówczas upada komponent awersji (aversio), który, jak podkreślają, w udowodnieniu przymusu lub bojaźni ma zasadnicze znaczenie ${ }^{56}$.

W części rozstrzygającej wyroku, ponens używając zwyczajowych formuł przewidzianych dla orzeczeń rotalnych, przedstawia decyzję turnusu, który pod przewodnictwem sędziego Jaira Ferreiry Pena, dnia 18 kwietnia 2012 roku, wydał wyrok pozytywny z tytułu symulacji częściowej ze strony powódki z powodu wykluczenia bonum prolis. Do wyroku dodano klauzulę zakazującą jej zawarcia nowego związku, bez uprzedniej zgody ordynariusza miejsca.

\section{Uwagi końcowe}

Sprawę o nieważność małżeństwa Viglevanen. prowadzono z dwóch tytułów: symulacji częściowej w postaci wykluczenia dobra potomstwa po stronie powódki oraz ciężkej bojaźńi również po jej stronie.

Ustosunkowując się do motywów prawnych dotyczących pierwszego tytułu należy stwierdzić, że ponens nie skupił uwagi na doktrynalnie ugruntowanym rozróżnieniu między symulacją całkowitą i symulacją częściową, ale odniósł się w sposób szczególny do kwestii prawnie relewantnej intencji odrzucenia zrodzenia potomstwa oraz jego wychowania w pryzmacie teleologicznej struktury prawnej małżeństwa. Argumentował, powołując się na treść kan. $1055 \$ 1$ KPK/83, że jeśli małżeństwo z natury swej skierowane jest ku zrodzeniu i wychowaniu potomstwa, to wykluczenie bonum prolis skutkuje nieważnością związku. Dodał, iż zakresowo wykluczenie to obejmuje określone działania, podejmowane w momencie zawierania małżeństwa, godząc w porządek naturalny, a co się z tym wiąże, naruszając

\footnotetext{
56 Por. TAMżE.
} 
tym samym ład obiektywny ${ }^{57}$. Na poparcie tego została przywołana koncepcja św. Tomasza z Akwinu, który unikanie poczęcia potomstwa i przeszkadzanie jego zrodzeniu postrzegał w kategoriach intencji odrzucenia go w samych jego zasadach (in principiis).

Należy podkreślić istotny problem, któremu audytor rotalny poświęcił szczególną uwagę w części prawnej wyroku, a mianowicie zagadnienie woli domniemanego symulanta. Stąd rozróżnienie na wolę aktualną, działającą w momencie wyrażania zgody małżeńskiej; wirtualną, obecną jeszcze przed zawarciem małżeństwa; oraz habitualną, mającą znaczenie, o ile prowadzi do podjęcia konkretnego pozytywnego aktu mającego na celu symulację konsensu. Element wolitywny, jego zdaniem, w procesie formacyjnym konsensu $\mathrm{z}$ tytułu symulacji posiada walor fundamentalny. Cała trudność bowiem w dowodzeniu polega na wykazaniu motywacji i pełnej świadomości nupturienta $\mathrm{w}$ fałszywym, niezgodnym $\mathrm{z}$ wewnętrznym przekonaniem, wyrażeniu woli na zewnątrz ${ }^{58}$.

Nie ulega wątpliwości, iż dowodzenie symulacji nie należy do łatwych. Redaktor orzeczenia w części in facto, wykazał jednak, że w przedmiotowej sprawie, w celu jej udowodnienia, został przeprowadzony zarówno dowód bezpośredni, jak i pośredni. Ten pierwszy bazujący na oświadczeniu symulanta, to potwierdzenie w zeznaniach matki i innych świadków w sprawie, którzy wiedzieli bezpośrednio od powódki, że nie chce ona potomstwa z pozwanym, a także potwierdzające to czyny. Powódka oznajmiła matce, jeszcze przed zawarciem małżeństwa, że nie chce mieć w nim dzieci z pozwanym, ale ta zbagatelizowała to, traktując jako przejaw niedojrzałości, która z upływem czasu minie. Dopiero sąd apelacyjny przypisał zeznaniom matki właściwe znaczenie, udowadniając, że wyznanie powódki oraz stałe przyjmowanie przez nią antykoncepcji jest potwierdzeniem jej woli symulowania zgody małżeńskiej, poprzez wykluczenie dobra potomstwa.

57 Por. W. Góralski, Matrimonium facit consensus..., s. 273.

58 Por. A. GonzÁlez Alonso, Elementi di prova nella simulazione totale nella giurisprudenza recente della Rota Romana, Ius Ecclesiae 28 (2016), s. 635. 
Równie ważne są w kontekście stosowania antykoncepcji zeznania świadków, farmaceutów i lekarza, którzy nie tylko dostarczali powódce te środki, ale potwierdzili, że stosowała je tylko dla uniknięcia potomstwa, bez kontekstu terapeutycznego, oraz zeznali, że pozwana wyraźnie o tym mówiła i nie czuła żadnej głębszej więzi z pozwanym.

Turnus nadał powyższym oświadczeniom powódki walor przyznania pozasądowego, pochodzącego z czasu „niepodejrzanego”, poprzedzającego wniesienie skargi. Służy ono wzmocnieniu przyznania sądowego, którego powódka dokonała przed sędzią, i którego właściwej oceny dokonał zarówno sąd apelacyjny drugiego stopnia, jak i turnus rotalny. To bowiem do sądu należy ocena wartości przyznania symulanta, którego dokonuje po rozważeniu wszystkich okoliczności (por. kan. $1537 \mathrm{KPK} / 83)^{59}$.

Przy rozważaniu wartości przyznania pozasądowego i sądowego symulującego, istotną rolę odgrywa przekonanie się o jego wiarygodności. Judykatura rotalna przykłada dużą wagę do tej kwestii ${ }^{60}$. $\mathrm{Z}$ treści komentowanego wyroku wynika, iż w przeciwieństwie do pozwanego mężczyzny, powódkę uznano za osobę wiarygodną. Jak wspomniano wyżej, jej oświadczenie zostało potwierdzone także przez wiarygodnych świadków oraz okoliczności sprawy Viglevanen. To właśnie one, występujące przed zawarciem małżeństwa, w trakcie jego zawarcia oraz po zawarciu związku przez strony, obok przyczyny symulacji (causa simulandi), decydowały o sposobie dowodzenia ${ }^{61}$. Jurysprudencja rotalna uznaje udowodnienie przyczyny za dowód najważniejszy ${ }^{62}$. Przyczyna powinna być nie tylko poważna, ale

59 Por. Dec. c. Alwan z 12.04.2002, RRD 94 (2002), s. 237; Dec. c. Stankiewicz z 25.04.2002, RRD 94 (2002), s. 285.

${ }^{60}$ Por. L. Świto, Exclusio boni prolis jako tytuł nieważności małżeństwa, Olsztyn 2003, s. 88-89.

61 Por. A. PAwŁowski, Il «bonum fidei» nella tradizione canonica e la sua esclusione nella recente giurisprudenza rotale, Roma 2002, s. 338; H. FRANCESCHI, Esclusione del «bonum fidei»: i profili probatori, w: Il «bonum fidei» nel diritto matrimoniale canonico, Città del Vaticano 2013, s. 197-198.

62 Por. K.E. Boccafola, Le presunzioni giudiziarie nella giurisprudenza in materia di simulazione, w: Presunzioni e matrimonio, Città del Vaticano 2012, s. 217. 
również proporcjonalna $\mathrm{w}$ odniesieniu do dobra samego małżeństwa $^{63}$. W omawianej sprawie wykazano, iż tym, co skłoniło powódkę do symulowania zgody małżeńskiej przez odrzucenie bonum prolis, był brak miłości do pozwanego, poddanie się presji rodzinnej i społecznej oraz chęć „wyrwania się” z trudnego środowiska, w którym się wychowała. Fakty te znalazły potwierdzenie w okolicznościach sprawy, które zgodnie z zasadami dowodzenia powinny, w przeciwieństwie do domniemań, zostać udowodnione, a nie dedukcyjnie wywiedzione lub dopuszczone jako hipotezy ${ }^{64}$.

Należy zauważyć, iż w analizowanej sprawie takimi udowodnionymi okolicznościami sprawy były szeroko opisane przez powódkę i świadków warunki życia w małej sycylijskiej wiosce, trudne warunki wychowawcze powódki, lęk o utratę reputacji, a nade wszystko stałe stosowanie przez nią antykoncepcji, które miało miejsce zarówno przed, jak i po zawarciu małżeństwa. Chociaż powódka nie wykluczała prawa do aktów małżeńskich jako takich, przez stosowanie antykoncepcji doprowadziła do stanu, że nie były one naturalne i od początku zamknięte na możliwość poczęcia. Należy zatem zauważyć, iż w sprawie Viglevanen. wolę wykluczającą udowodniono także po zastosowaniu dowodzenia pośredniego.

Na stopniu apelacyjnym wniesiono także, jako autonomiczny tytuł zawarcia małżeństwa, ciężką bojaźń, która miała przybrać postać bojaźni szacunkowej, wywołanej przez matkę powódki. Audytorzy turnusu rotalnego odstąpili jednak od orzekania $\mathrm{z}$ tego tytułu, argumentując to nie tylko tym, że istniała wątpliwość co do natury nacisków ze strony matki w kierunku zawarcia małżeństwa przez powódkę, ale uznając przede wszystkim, tytuły symulacji i ciężkiej bojaźni oparte na tych samych faktach jako absorbujące się, stąd $\mathrm{w}$ formule wątpliwości na stopniu rotalnym połączono je, używając

\footnotetext{
63 Por. B. Glinkowski, Symulacja całkowita zgody małżeńskiej w orzecznictwie Roty Rzymskiej (1965-1995)..., s. 60-65.

64 Por. A.A. CEDIllo, Il valore presuntivo delle relazioni extramatrimoniali, w: Questiones selectae de re matrimoniali ac processuali, Città del Vaticano 2018, s. 338.
} 
formuły „et/vel” ${ }^{65}$. Tym sposobem implementowano występujące w doktrynie stanowisko dotyczące niekompatybilności i absorpcji wymienionych tytułów. Należy przeto zwrócić uwagę, iż skoro turnus rotalny doszedł do przekonania o nieważności małżeństwa z tytułu symulacji, który nie był ostatni w logicznej kolejności, to musiał się więc zastanowić, jak odpowiedzieć na tytuł bojaźni, który został przezeń absorbowany. Sąd nie mógł zatem odpowiedzieć na niego ani affirmative (bo na podstawie tych samych faktów orzekł już z innego, "głębszego" tytułu, jakim była symulacja) ani negative (bo te same fakty prawne nie mogą prowadzić do wniosków sprzecznych) ${ }^{66}$. Dlatego też podjęto decyzję o nieorzekaniu z tytułu ciężkiej bojaźni.

\section{References}

Źródła

Codex Iuris Canonici auctoritate Joannis Pauli PP. II promulgatus, 25.01.1983, AAS 75 (1983), pars II, s. 1-317.

Codex Iuris Canonici Pii X Ponti cis Maximi iussu digestus, Benedicti Papae XV auctoritate promulgatus, AAS 9/II (1917), s. 2-593.

Dec c. PINTo z 30.07.1969, SRRD 61 (1969).

Dec. c. Pinto z 28.10.1983, RRD 75 (1983).

Dec. c. Alwan z 12.04.2002, RRD 94 (2002).

Dec. c. Boccafola z 17.01.2002, RRD 94 (2002).

Dec. c. BRUNO z 8.07.1975, SRRD 67 (1975).

Dec. c. BRUno z 15.04.1983, RRD 75 (1983).

Dec. c. BURKe z 19.10.1995, RRD 87 (1995).

Dec. c. CIANi z 30.10.2002, RRD 94 (2002).

Dec. c. De Jorio z 8.01.1971, SRRD 73 (1971).

Dec. c. De Jorio z 22.01.1969, SRRD 61 (1969).

Dec. c. DefFilippi z 13.07.2000, A. 77/00, n. 15 (nieopublikowany).

Dec. c. Di Felice z 16.10.1976, SRRD 68 (1976).

Dec. c. Di Felice z 25.06.1971, SRRD 63 (1971).

Dec. c. ErLebach z 13.12.2007, RDD 99 (2007).

65 Por. Dec. c. J. Ferreira Pena z 18.04.2012, n. 3.

${ }^{66}$ Por. R. SobAŃski, Orzekanie nieważności małżeństwa $z$ dwu (lub więcej) tytułów wadliwego konsensu, Ius Matrimoniale 5 (11) (2000), s. 144. 
Dec. c. EwERS z 13.02. 1965, SRRD 57 (1965).

Dec. c. EwERS z 19.04.1972, SRRD 74 (1972).

Dec. c. Felici z 11.01.1955, SRRD 47 (1955).

Dec. c. LANVERSIN z 21.02.1990, RRD 82 (1990).

Dec. c. LANVERSIN z 31.07.1990, RRD 82 (1990).

Dec. c. Monier z 12.04.2002, RRD 94 (2002).

Dec. c. PARISElla z 16.06.1983, SRRD 75 (1983).

Dec. c. Sabatini z 11.11.1962, RRD, 52 (1962).

Dec. c. StANKIEWICZ z 12.07.1966, RRD 88 (1996).

Dec. c. StANKIEWICZ z 25.04.2002, RRD 94 (2002.

Dec. c. STANKIEWICZ z 29.07.1980, RRD 72 (1980).

Dec. c. Di Felice z 29.03.1969, SRRD 61 (1961).

Dig. 23, 2, 30 .

Dig. 23, 2, 30; C. 4, 22.

FRANCISZEK, List apostolski motu proprio „Mitis Iudex Dominus Iesus”, reformujacy kanony Kodeksu Prawa Kanonicznego dotyczące spraw o orzeczenie nieważności małżeństwa. List apostolski motu proprio „Mitis et misericors Iesus”, reformujacy kanony Kodeksu Kanonów Kościołów Wschodnich dotyczące spraw o orzeczenie nieważności (tekst łacińsko-polski), Tarnów 2015.

S. Thomas Aq., Summa Theologica, Suppl., q. 49, art 3.

Viglevanen. Nullitatis matrimonii. Sent. 61/2012, Dec. c. J. Ferreira PenA z 18.04.2012, RRD 104 (2012), s. 106-116.

\section{Literatura}

BocCAfola K.E., Le presunzioni giudiziarie nella giurisprudenza in materia di simulazione, w: Presunzioni e matrimonio, Città del Vaticano 2012.

CEDILlo A.A., Il valore presuntivo delle relazioni extramatrimoniali, w: Questiones selectae de re matrimoniali ac processuali, Città del Vaticano 2018.

Dzierżon G., Niezdolność do zawarcia małżeństwa jako kategoria kanoniczna, Warszawa 2002.

Fedele P., L',oridantio ad prolem” nel matrimonio canonico, Milano 1962.

FRANCESCHI H., Esclusione del «bonum fidei»: i profili probatori, w: Il «bonum fidei» nel diritto matrimoniale canonico, Città del Vaticano 2013.

GLinkowsкi B., Symulacja całkowita zgody małżeńskiej w orzecznictwie Roty Rzymskiej (1965-1995), Poznań 2004.

GonzÁlez Alonso A., Elementi di prova nella simulazione totale nella giurisprudenza recente della Rota Romana, Ius Ecclesiae 28 (2016), s. 611-636.

GóRALSKI W., Matrimonium facit consensus. Z orzecznictwa Trybunału Roty Rzymskiej w sprawach o nieważność małżeństwa rozpoznanych z tytułów dotyczących zgody małżeńskiej (1997-2016), t. 3, Płock 2018. 
PAwŁowski A., Il «bonum fidei» nella tradizione canonica e la sua esclusione nella recente giurisprudenza rotale, Roma 2002.

Sснӧсн N., Le presunzioni legali nel matrimonio: in materia di consenso (can. 1096 \$ 2; 1101 \$ 1; 1107 CIC), w: Presunzioni e matrimonio, Libreria Editrice Vaticana 2012.

Sobański R., Orzekanie nieważności małżeństwa z dwu (lub więcej) tytułów wadliwego konsensu, Ius Matrimoniale 5 (11) (2000), s. 139-150.

Św Iтo L., Exclusio boni prolis jako tytuł nieważności małżeństwa, Olsztyn 2003.

\section{Nota o autorze}

Ks. Rafał Kamiński CSMA - doktor nauk prawnych w zakresie prawa kanonicznego, adiunkt w Katedrze Kanonicznego Prawa Małżeńskiego i Rodzinnego na Wydziale Prawa Kanonicznego UKSW, prodziekan Wydziału Prawa Kanonicznego UKSW, sekretarz redakcji „Ius Matrimoniale”, sędzia Sądu Metropolitalnego Warszawskiego, członek Komisji Prawnej Konferencji Wyższych Przełożonych Zakonów Męskich w Polsce. 